\title{
GRG Profiles: David A. Lieberman
}

\author{
David A. Lieberman ${ }^{1}$
}

Published online: 6 October 2015

(c) Springer Science+Business Media New York 2015

Life is an acquisition of lessons-some learned better than others. Here are a few of the lessons I have learned along the way.

\section{Lesson 1: Get Involved}

I was born in St. Louis, Missouri, and retain two important qualities of that heritage: a very flat " $A$ " when I speak and an enduring love for the St. Louis Cardinals. Growing up in the Eisenhower postwar, 1950s, I experienced a world far different from that of my parents, who had known depression and World War. I knew about Russians, the Cold War, and the existential threat of the atomic bomb. My parents became community activists in our suburb of University City, just west of St. Louis, and provided important role models for my siblings and me. My father served on the City Council and my mother on the School Board, each for more than 25 years. These were elected, but unpaid, positions. Although my neither of my parents was unlikely to be leader, their message was clear: It is not sufficient to sit in the audience of life; it is important to get up on stage and try to make a difference- to try to make your community a better place.

David A. Lieberman

lieberma@ohsu.edu

1 Division of Gastroenterology and Hepatology, Oregon Health and Science University, L461, 3181 SW Sam Jackson Park Rd., Portland, OR 97239, USA

\section{Lesson 2: Mentorship}

As a student in the Honors College at the University of Michigan, I learned rather quickly that in a place like Michigan, you should find your smaller community within the larger university and take advantage of the diversity and offerings of a great school, one of which was a National Institutes of Health (NIH) training grant summer program for undergraduate students in the Department of Physiology. I was fortunate to apply successfully for this summer research stint and was quickly ushered into a world of brilliant minds and inquiry. My first mentor was John Faulkner, a Ph.D. exercise physiologist from Canada, who welcomed me into his laboratory. We trained guinea pigs on treadmills to determine whether we could change their skeletal muscle to a more aerobic type of cells with exercise. Since the diaphragm is a skeletal muscle, we asked if we could train the diaphragm to be a more aerobically efficient muscle. Our experiments demonstrated that this was possible, with implications for improving pulmonary function in patients with pulmonary disease. My first publication was produced on a portable SmithCorona typewriter (with actual carbon copies made of real carbon). It was returned to me filled with red ink, and then retyped (no cutting and pasting) for another round of edits by Dr. Faulkner. He gently, but firmly, helped me become a better writer, and after 10 rounds of revisions, we submitted the paper to the American Journal of Physiology, where it was published in 1972 [1]. My first oral presentation was at a national meeting of the Physiology Society in 1972. Before the meeting, I had to practice before the Department of Physiology, chaired by the legendary Horace Davenport of acid-base fame. The presentation at the national meeting was easy after dealing with the tough questions from Dr. Davenport and other members of the 
department. There were many lessons from this experience, but chief among them was the importance of good mentorship. I learned that we all stand on the shoulders of those who came before us. I have been blessed with wonderful mentors and friends who have been my guides along my journey.

\section{Lesson 3: Becoming a Doctor}

I attended the University of Michigan Medical School and had another summer experience, which really cemented my love of medicine. I did an "externship" in the little town of Tecumseh, Michigan, which had been the site of a population-based study of the entire population designed to examine multiple disease risk factors, similar to the more famous Framingham Study (in Massachusetts). Dr. Carlton Cook, the beloved town doctor, seemed to be type-cast from another era. Basically, he did everything. In the morning, he would operate in the small community hospital (removing tonsils, gallbladders, appendices), deliver babies, and then, in the afternoon, he would see patients in an outpatient clinic. In his spare time, he served on the City Council, sang in a barbershop quartet, and flew a small two-engine plane for fun on weekends. I would meet him at the hospital every morning, scrub in for surgery, and get to do a little suturing and help deliver babies. What a heady experience right after my first year of medical school! At noon, we would walk 5 min to his house for lunch with his entire family and then return to the clinic for the afternoon, where I would really get to know his patients. I flew with him around southern Michigan in the little two-seater plane on several weekends. More than anyone, he taught me the art of medicine, the importance of getting to know your patients, and how to recognize your limitations. He also taught me the importance of having balance in your life. He worked hard, spent "quality time" with his family, and had a lot of fun. When classes resumed for the second year of medical school, I was hooked and knew with great certainty that I enjoyed clinical medicine. The clinical years of medical school created another challenge for me, because I liked almost every rotation and had difficulty deciding which specialty to select for internship. In the end, it was internal medicine, due to its many available options.

\section{Lesson 4: Family}

On my first day as an undergraduate at Michigan, I met a young woman in my dorm who was part of the welcoming committee. We became part of a large circle of friends from the Honors College. Two years later, we both spent a summer in Ann Arbor and realized that we were becoming more than friends. Donna pursued her Masters degree in Social Work while I was in medical school, and we eventually were married between my second and third year of medical school in 1974. Throughout my life and career, she has been a reliable sounding board for my sometimes crazy ideas, critiqued my early lectures, and provided me with honest feedback; she has always been there when I needed support.

\section{Lesson 5: Gastroenterology}

During my last year at Michigan, I obtained permission to rotate to Seattle, San Francisco, and St. Louis, where we could stay with family and minimize the cost. It was in Seattle that we fell in love with the American northwest, traveling to Portland twice to interview and see the city. Portland became a trendy city after our arrival, so perhaps we should take a little credit. Portland had most of what I might want from an urban center and with incredible geography literally minutes away. The academic community at Oregon Health and Science University was collegial, collaborative, and supportive. I quickly felt at home and started to think about whether to pursue an academic or purely clinical career. After my first internship rotation, I was approached by my attending, a gastroenterologist, Ronald Katon, who told me to think about gastroenterology (GI). As I became more familiar with the GI community, I realized it was just that - a community of really likeable physicians who enjoyed a nice mix of cognitive and procedural activities, which I found appealing. After spending a year as medical chief resident, I decided to give academia a try, with a focus on clinical research. After GI fellowship at Oregon, I joined the faculty at the Portland Veterans Administration (VA) Medical Center, embarking on a new chapter of my life.

\section{Lesson 6: Asking Questions and Overcoming Obstacles}

As I started my career as a faculty member, I realized that the practice of GI (and other specialties) was not evidencebased, providing much material for potential research. I learned to ask questions about what we do every day. My career was launched with the support of a remarkable mentor, Emmet Keeffe. We became close friends and running partners during my fellowship and also backpacking in the Oregon Cascades. He was a career mentor and an invaluable personal mentor as well. As Donna and I started our young family, we spent time with Emmet and 
Melenie Keeffe, who became our "parent" mentors. Emmet, clear thinker and superb editor, worked with me on early manuscripts and projects.

My philosophy about our endoscopy unit was that every patient could potentially be a subject of a study if we framed the right questions. Early work focused on gastroesophageal reflux disease (pre-proton pump inhibitor era) and GI bleeding, because these were most common reasons for endoscopy in the early 1980s. I was fortunate to have wonderful collaborators, and papers on the management of reflux disease [2-5] and variceal bleeding [6] followed.

Academic medicine offered many wonderful challenges. I have thoroughly enjoyed being surrounded by learners who ask questions that I cannot answer and who challenge me to learn more. I am reminded of a quotation from William Butler Yeats: "Education is not the filling of a pail, but the light of a fire." I hope that I have lit a few fires along the way.

\section{Lesson 7: Game Changer}

The question that changed my career came from a GI fellow. We were performing screening sigmoidoscopy in 1987, and he asked, "How many patients with adenomas are not detected by sigmoidoscopy?" The answer was not known but could be answered by performing screening colonoscopy to determine what was missed. This question launched me down a path that continues to this day. We performed some pilot studies to determine the feasibility of screening colonoscopy [7], and, in 1993, received funding from the VA to conduct a large VA Cooperative Study (\#380) — the largest study to evaluate colorectal cancer screening with colonoscopy, compare results with fecal occult blood testing and sigmoidoscopy, and measure risk factors for advanced neoplasia. Since the VA study was not initially funded, it would have been easy to give up on this idea. But with the support of the Director of the Cooperative Studies program, Daniel Deykin, I was encouraged to revise the proposal and resubmit what I now realize was a much better proposal than the original. The lesson here was that although there will inevitably be bumps in the road, one key to success is picking yourself up, learning from the experience, and moving forward. There is an African proverb that guides me: "Smooth seas do not make skillful sailors."

The VA Cooperative Study \#380 provided an opportunity to collaborate with some remarkable investigators at 13 VA centers around the country to recruit over 3000 patients. In addition to the GI specialists, we worked with superb statisticians (David Weiss and Joseph Selby, who became the head of Patient-Centered Outcomes Research
Institute [PCORI]), nutrition expert Walter Willett, oncologist Harinder Garewal, and a tireless pathologist, Gregory Chejfec. Arthur Schatzkin from the National Cancer Institute provided support to create a blood and tissue repository. Publications in The New England Journal of Medicine, The Journal of the American Medical Association, Annals of Internal Medicine, Gastroenterology, Clinical Gastroenterology and Hepatology, and Gastrointestinal Endoscopy [8-14] helped inform guidelines on colorectal cancer screening and surveillance and influenced the US Congress to include colonoscopy as a funded screening test for Medicare beneficiaries in 2001. A few appearances with Katie Couric on the Today Show provided me with my " 15 min of fame" but also enabled me to deliver the message that colon cancer screening could be effective. Screening rates have skyrocketed in the past 15 years, thanks in part to these efforts [15]. The development of guidelines soon followed with participation on the US Multi-Society Task Force on Colorectal Cancer and an opportunity to work closely with Sidney Winawer, Ann Zauber, Bernard Levin, Robert Smith, John Bond, Wendy Atkin, and Douglas Rex-affectionately known as the "Colon Mafia" [16, 17].

\section{Lesson 8: More Questions-Why Do We Do Endoscopy and Do We Improve Outcomes?}

Another question lurking in the 1990s dealt with endoscopy. By 2000, it was estimated that GI specialists performed more than 20 million endoscopic procedures in the USA. And yet, basic questions about who underwent endoscopy (demographics), why they did (indications), procedural outcomes (results), and procedural quality were unknown. I had an opportunity to help direct an NIH workshop on endoscopic research priorities in 1998 [18]. With the support of the American Society for Gastrointestinal Endoscopy (ASGE), we developed an electronic tool to capture data for endoscopy. At the time, this was one of the first applications of computer technology to collect patient data. The concept was novel, and I was inspired by a quotation from Albert Einstein: "If at first the idea is not absurd, there is no hope for it." We developed an endoscopic report generator that provided the endoscopist a report and sent data electronically to a central repository, termed the Clinical Outcomes Research Initiative (CORI), which received data from 80 diverse practices around the USA to ask and answer some basic questions about endoscopy. We were funded by the National Institute of Diabetes and Digestive and Kidney Diseases (NIDDK) in 1999, and to date, we have generated 100 publications from this project [19-22]. The development and measurement of endoscopy quality metrics followed [23-25]. 


\section{Lesson 9: Getting Involved in My Community (See Also Lesson 1)}

Lessons from my parents about not sitting on the sidelines of life were never forgotten. Opportunities to get involved with my GI community came initially from the ASGE, due in part to my mentor, Emmet Keeffe. I chaired the ASGE Research Committee, was Associate Editor of Gastrointestinal Endoscopy, and then became an ASGE Governing Board member and ultimately President of ASGE in 2001-2002. In the American Gastroenterological Association (AGA), I was involved in several committees and task forces, became an Associate Editor of Gastroenterology, and then joined the AGA Board as the Clinical Research Counselor. I served on the NIH Commission for Digestive Diseases in 2008, to develop priorities for GI research. These experiences have enriched my career and taught me the importance and joy of giving back to the profession, which has nourished me and resulted in many lifelong friendships, which I deeply cherish. At home, I became the Chief of the GI/Hepatology Division at Oregon Health and Science University and derived great joy from watching the success of my faculty. The opportunity to help nurture junior faculty provides a very singular reward for taking on administrative positions. I have always measured my success as a leader by the success of the members of my division.

\section{Lesson 10: Family and Friends}

I do have a life outside of my work, which I value. I spend time outside hiking and bike-riding with friends. I have had amazing opportunities to travel throughout the world, explore new places, their history and culture, and develop friendships around the world. I am an avid reader of nonmedical fiction and non-fiction, the New Yorker, and the New York Times and belong to a men's book club that meets monthly.

As I reflect back on my life, I appreciate the opportunities that I have had to grow and evolve professionally and to be nurtured by wonderful friends and colleagues throughout the world. I have been proud to help mentor and work with some amazing people and bask in the glow of their growth and success. But I am especially blessed with my family and wonderful friends who continue to nurture me. My three children are now adults, each pursuing his or her passion and stepping forward on to the stage of life.

My career has been about asking questions about what we do every day in medicine. I stand on the shoulders of giants who preceded me, learned from wonderful colleagues and friends, and I hope I have positively contributed something to the next generation that will follow me. It has been such a privilege and honor to have an opportunity to make a small contribution to our knowledge. What a great ride!

Compliance with ethical standards

Conflict of interest None.

\section{References}

1. Lieberman DA, Maxwell LC, Faulkner JA. Adaptation of guinea pig diaphragm muscle to aging and endurance training. Am J Physiol. 1972;222:556-560.

2. Lieberman DA, Keeffe EB. Treatment of severe reflux esophagitis with cimetidine and metoclopramide. Ann Int Med. 1986;104:21-26.

3. Lieberman DA. Medical therapy of chronic reflux esophagitis: long-term followup. Arch Int Med. 1987;147:1717-1720.

4. Lieberman DA, Oehlke M, Helfand M, GORGE Consortium. Risk factors for Barrett's esophagus in community-based practice. Am J Gastroenterology. 1997;92:1293-1297.

5. Inadomi JM, Sampliner R, Lagergren J, Lieberman D, Fendrick AM, Vakil N. Screening and surveillance for Barrett's esophagus in high-risk populations: a cost-utility analysis. Ann Intern Med. 2003;138:176-186.

6. Stiegmann GV, Goff JS, Michaletz PA, et al. Endoscopic sclerotherapy as compared with endoscopic ligation for bleeding esophageal varices. $N$ Engl J Med. 1992;326:1527-1532.

7. Lieberman DA, Smith FW. Frequency of isolated proximal colonic polyps among patients referred for colonoscopy. Arch Int Med. 1988;148:473-475.

8. Lieberman DA, Weiss DG, Bond JH, Veterans Affairs Cooperative Study Group 380. Use of colonoscopy to screen asymptomatic adults for colorectal cancer. $N$ Engl $J$ Med. 2000;343:162-168.

9. Lieberman DA, Weiss DG, VA Cooperative Study Group \#380. One-time screening for colorectal cancer with combined fecal occult-blood test and examination of the distal colon. $N$ Engl $J$ Med. 2001;345:555-560.

10. Lieberman DA, Prindiville S, Weiss DG, Willett W. Risk factors for advanced colonic neoplasia and hyperplastic polyps in asymptomatic individuals. JAMA. 2003;290:2959-2967.

11. Collins JF, Lieberman DA, Durbin TE, Weiss DG. Accuracy of screening for fecal occult blood on a single stool sample obtained by digital rectal examination: a comparison with recommended sampling practice. Ann Intern Med. 2005;142:81-85.

12. Schoenfeld P, Cash B, Flood A, et al. Colonoscopic screening of average-risk women for colorectal neoplasia. $N$ Engl J Med. 2005;352:2061-2068.

13. Lieberman DA, Weiss DG, Harford WV, et al. Five year colon surveillance after screening colonoscopy. Gastroenterology. 2007;133:1077-1085.

14. Martinez ME, Baron JA, Lieberman DA, et al. A pooled analysis of advanced colorectal neoplasia diagnoses following colonoscopic polypectomy. Gastroenterology. 2009;136:832-841.

15. Lieberman DA. Screening for colorectal cancer. $N$ Engl J Med. 2009;361:1179-1187.

16. Levin B, Lieberman DA, McFarland B, et al. Screening and surveillance for early detection of colorectal cancer and adenomatous polyps, 2008: a joint guideline from the American Cancer Society, the US Multi-Society Task Force on Colorectal Cancer, and the American College of Radiology. CA Cancer J Clin. 2008;58:130-160. 
17. Lieberman DA, Rex DK, Winawer SJ, Giardiello FM, Johnson DA, Levin TR. Guidelines for colonoscopy surveillance after screening and polypectomy: a consensus update by the US MultiSociety Task Force on Colorectal Cancer. Gastroenterology. 2012;143:844-857.

18. Lieberman DA. National Institutes of Health Workshop on Endoscopic Research Priorities: introduction. Gastrointest Endosc. 1999;49:S1-S2.

19. Lieberman DA, Fennerty MB, Morris C, Holub J, Sonnenberg A. Endoscopic evaluation of patients with dyspepsia: results from the national endoscopic data repository. Gastroenterology. 2004;127:1067-1075.

20. Lieberman D, Holub J, Moravec M, Eisen G, Peters D, Morris C. Prevalence of colon polyps detected by colonoscopy screening in asymptomatic black and white patients. JAMA. 2008;300: $1417-1422$.

21. Ko CW, Riffle S, Michaels L, et al. Serious complications within 30 days of screening and surveillance colonoscopy: a multicenter study. Clin Gastroenterol Hep. 2010;8:166-173.
22. Lieberman D, Holub J, Morris C, Logan J, Williams JL, Carney P. Low rate of large polyps $(>9 \mathrm{~mm})$ within 10 years after an adequate baseline colonoscopy with no polyps. Gastroenterology. 2014;147:343-350.

23. Rex DK, Bond JH, Winawer S, et al. Quality in the technical performance of colonoscopy and the continuous quality improvement process for colonoscopy: recommendations of the U.S. Multi-Society task force on colorectal cancer. Am J Gastroenterol. 2002;97:1296-1308.

24. Lieberman D, Nadel M, Smith R, et al. Standardized colonoscopy reporting and data system (CO-RADS): report of the Quality Assurance Task Group of the National Colorectal Cancer Roundtable. Gastrointest Endosc. 2007;65:757-766.

25. Lieberman DA, Faigel DO, Logan J, et al. Assessment of colonoscopy quality: results from a multi-center consortium. Gastrointest Endosc. 2009;69:645-653. 